\title{
Development of Information Website for PAUD AI Lathifiyah IV as Promotion Media and School
}

\section{Profiles}

\author{
Suci Nurfauziah1 \\ sucinurfauzi@polinema.ac.id
}

\begin{abstract}
The website is a medium for delivering information and online promotional media that the broader community can access. Generally, every school should have a website as a complete school profile. However, so far, the information and promotion of PAUD Al Lathifiyah IV Lamongan have only been limited to word of mouth (WOM) through local people. This study aims to develop the PAUD Al Lathifiyah IV website as a promotional media and school profile. Implementation of PAUD website used CMS WordPress. Based on the research results, the PAUD AI Lathifiyah IV website could be applied and run well and was responsive on all browser devices. With the PAUD Al Lathifiyah IV website, the way of delivering information and promotions was more effective and accurate than information obtained by word of mouth.
\end{abstract}

Keywords: $\quad$ Website, Promotion, School profile, PAUD AI Lathifiyah IV Lamongan

\begin{abstract}
Abstrak: $\quad$ Website merupakan media penyampaian informasi dan media promosi online yang dapat diakses oleh masyarakat luas. Umumnya setiap sekolah seharusnya memiliki website sebagai profil sekolah yang lengkap. Selama ini informasi dan promosi PAUD Al Lathifiyah IV Lamongan hanya sebatas dari mulut ke mulut (WOM-Word of Mouth) melalui orang sekitar. Tujuan penelitian ini untuk mengembangkan website PAUD AI Lathifiyah IV sebagai media promosi dan profil sekolah. Implementasi website PAUD dengan menggunakan CMS WordPress. Berdasarkan hasil penelitian bahwa website PAUD Al Lathifiyah IV dapat diaplikasikan dan berjalan dengan baik dan responsif pada semua perangkat browser. Adanya website PAUD Al Lathifiyah IV cara penyampaian informasi dan promosi menjadi lebih efektif serta lebih akurat dari pada informasi yang diperoleh dari mulut ke mulut.
\end{abstract}

Kata Kunci: $\quad$ Website, Promosi, Profil Sekolah, PAUD Al Lathifiyah IV Lamongan

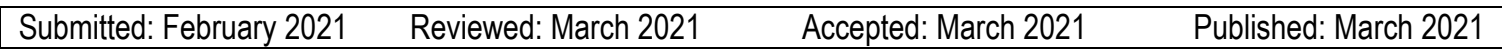

${ }^{1}$ Politeknik Negeri Malang 
E ducation must be carried out from an early age, whether in a formal or informal education environment, to create a quality generation. Early childhood is children who are less than six years old and are experiencing a period of growth, both physically and psychologically. According to Piaget in Sumantri, early childhood is a golden age for child development (Sumantri, 2005). Although early childhood education (PAUD) is not the main requirement for entering the basic education level, parents should understand its importance. Early childhood education begins for children aged 0-6 years; moreover, providing good education from an early age will greatly influence the development process.

Early childhood education is organized to develop skills that constitute basic education and develop oneself as a whole based on the principles of education as early as possible and throughout life. Several things must be developed in early childhood education, including developing habits related to emotional, social, moral, religious values, and independence and developing basic abilities that include cognitive, language, and motoric physical development (Musfiroh, 2008).

As previously explained about several things that must be developed in early childhood, in playgroup (KB) and kindergarten (TK) education, the main objectives are to achieve development, namely gross motoric physicality, physical health, religious values and moral, fine motor skills, cognitive (general knowledge and science), the concept of size and color pattern, the concept of numbers and letters, expressing emotions and language, and socio-emotional. Early childhood creativity can be pursued through games designed by educators at early childhood education institutions because with games, children can develop and integrate all their potential to be more creative. Educators' roles in children's play activities are to provide encouragement, guide play for children, and help children develop their potential to become creative children (Anhusadar, 2016).

Law No. 20 of 2003 concerning the National Education System, Chapter 1 Article 1, point 14 states that early childhood education is a coaching effort aimed at children from birth to 6 years of age; guidance is carried out by providing educational stimuli. This stimulus assists spiritual and physical growth and development so that children are ready to enter further education. On the other hand, the 2013 curriculum is a character and competency-based curriculum. The learning process for the 2013 early childhood education curriculum emphasizes authentic assessment and a scientific approach. The authentic assessment aims to determine the level of children's development in the learning process. Meanwhile, the scientific approach aims to shape children to think critically and creatively and have freedom of imagination (Rahelly, 2018).

As explained in the previous paragraphs, early childhood education emphasizes educational stimulation through play activities for children's development. Even though the current 2013 curriculum is competency-based, it still prioritizes children's learning while playing. Because in essence, early childhood (0-6 years) is when children play a lot.

The problem is that many people do not understand how the learning process in early childhood is. Parents only send their children to early childhood education without knowing the curriculum and what activities will be taught. Parents decide to enter their children into early childhood education, hoping that children will be intelligent, but they do not understand its meaning and purpose (Yani \& Indrawati, 2014). Many parents think narrowly, assessing early childhood education as just a place to play without providing meaningful lessons to benefit children's growth and development. According to a psychologist, Hartatik, many parents are paranoid if their children cannot read, write, and count when they register for primary school. Therefore, parents demand early childhood education institutions prioritize teaching reading, counting, and writing without prioritizing children's way of thinking and freedom. This action will make children depressed and reduce their interest in learning (Mubarok, 2017). Besides, many parents do not understand the purpose of early childhood education, so they tend to demand that PAUD schools 
emphasize arithmetic and writing and children who are fluent in reading after graduating from early childhood education, just like elementary education children.

On the other hand, Indonesia has entered the industrial era 4.0. Industry 4.0 is an industrial revolution concept based on continuous communication via the internet, allowing interaction and exchange of information between humans-humans-machines and between machines (Cooper, J., \& James, 2009). The industrial revolution era 4.0 (IR 4.0) is a trend of data exchange and the latest industrial and manufacturing technology automation. This term includes cloud computing, cyber-physical systems, the internet for everything, and cognitive computing. It raises information behavior in society. Information behavior is an effort to find information with a specific purpose due to a need. This society is characterized by the exchange of information and the use of high-intensity communication technology (llyasir, 2020).

The survey results by Asosiasi Penyelenggara Jasa Internet Indonesia [Indonesian Internet Service Providers Association] (APJII) in 2019-2020, the penetration of internet users in Indonesia was 73.7 percent, up from 64.8 percent in 2018. It is estimated that Indonesian internet users were 196.7 million users; this number was up from 171 million in 2019 or around 8.9 percent or 25.5 million users (www.kominfo.go.id, 2020). It indicates that the current information dissemination is mainly via the internet. Using internet facilities can penetrate time and space boundaries, one of which is through the website. The website can be accessed by many people and provides clear information. Information delivery through the website is more efficient and up-to-date. A website is a means of delivering information and online promotion media, which the wider community can access. Website is often used as a medium of information, marketing, education, promotion, and communication. Website is the right and effective choice as a promotional media because it is connected to the internet to be accessed and spread widely. Accurate, fast, and easy information delivery will accelerate the information to the broader community (Hasugian, 2018; Prawira \& Wardani, 2017; Rochman, Hanafri, \& Wandira, 2020).

In the world of education, websites are widely used as promotional media to introduce school information to the broader community, which is not limited to time (Andriyan, Septiawan, \& Aulya, 2020). The website's application can improve excellent quality education performance and competitiveness for the community. With the website, it is hoped that it will make it easier for schools, teachers, and school members to access information about the school and help the admin control and archive data and information (Afriansyah, Mubaroh, \& Pratiwi, 2021). The use of websites in the world of education as a media for promotion and school information has been widely applied and carried out, as research conducted (Rochman et al., 2020) at SMK Kartika, (Andriyan et al., 2020) implemented websites as a medium of information and image enhancement in SMK Dewi Sartika Tangerang, and (Afriansyah et al., 2021) created a website as a medium of information at SMA Negeri 1 Sungailiat.

In general, every school or institution should have a website that provides school-related information or is often referred to as a complete school profile to the community, likewise for early childhood education institutions. However, no early childhood education institutions in Lamongan had a website, nor did PAUD AI Lathifiyah IV Lamongan have an information website. So far, information and promotion related to PAUD AI Lathifiyah IV Lamongan have only been limited to word of mouth through local people and brochure distribution. Information dissemination with this brochure was only carried out once a year when new student enrollments were approaching, and it could not be done at any time due to limited costs. Besides, the activities and competitions carried out and won by PAUD AI Lathifiyah IV Lamongan were only known by the students' guardians who accompanied them during the event, and not many outsiders knew. Likewise, with the explanation regarding the school's curriculum, many parents did not understand it and had to ask the teacher directly. Thus, this study aims to develop the PAUD Al Lathifiyah IV Lamongan website as a promotional media and school profile. 
The method in this study consisted of three stages. The first stage was the preparation, the second stage was designing the website, and the third stage was implementation, as illustrated in Figure 1.

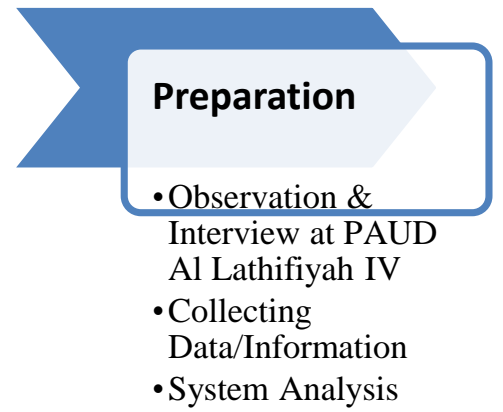

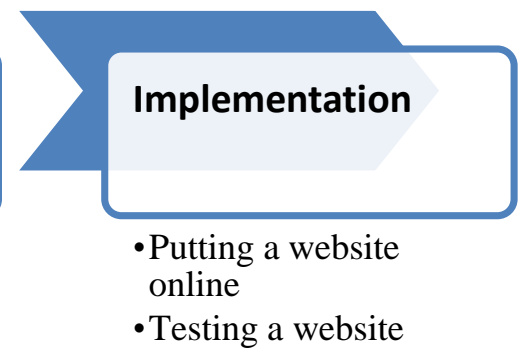

Figure 1. Research Procedure

\section{Preparing:}

At this preparation stage, observations and interviews were carried out first. The researcher interviewed the PAUD Al Lathifiyah IV school and asked for permission to do community service. Observations were made by observing the surrounding environment and PAUD AI Lathifiyah IV activities as information material on the website page. The required data/information was then collected, such as school profiles, curriculum, achievements, and other documentation. The final step in this preparation stage was to analyze the website before the next stage. Based on data/information, the researcher determined the theme and information for the appropriate website content.

\section{Website Development:}

This implementation stage comprised two activity steps: designing the website and building it. The first step determined the cms to be used. The information website for PAUD AI Lathifiyah IV was built on cms-based using WordPress. Next, a menu or navigation, layout, and content were designed. After the design stage, the next step was to build a website by first installing xampp and WordPress.

\section{Implementation:}

This implementation stage was to put the website online by registering on a paid domain. Before going online, the researcher discussed with the school about website names and domain names. Then, testing this website was necessary to find out the website's shortcomings and research. This website testing utilized the online GTMetrix tool. GTMetrix was to find out the performance score, including page speed, fully loaded time, total page size, optimization recommendations, and page load details, consisting of time, size, and the number of requests for a website page (Andriansyah, 2019; Setiawan \& Jati, 2012). GTMetrix was accessed online at the website address https://gtmetrix.com/. Any missing sections were described in terms of flaws and recommendations according to Google Page Speed and Yahoo Yslow. Of course, it was done with links to related articles that recommend troubleshooting. Therefore, the website owner could fix these deficiencies by the recommendations (Delta, 2016). The GTMetrix assessment is an alphabetical assessment, with A being the best. The GTMetrix score is based on the weight between the performance score $(70 \%)$ and the structure score $(30 \%)$. Performance assessment is a measure of the access speed and web pages' response, while the structure's value is a measure based on the web pages' structure, such as the use of CSS, a combination of CSS with images, etc. (GTMetrix, 2021). 


\section{Results}

Based on the data collection results through observation and interviews, it was revealed that in Lamongan, there was no early childhood education institution with a website; even government-owned early childhood education institutions did not have one. The observation and interview results with early childhood teachers in Al Lathifiyah IV Lamongan could be concluded with three main points. First, in PAUD AI Lathifiyah IV Lamongan, school promotion was limited to distributing brochures and spreading information by word of mouth (WOM). Second, PAUD AI Lathifiyah IV has already had social media (Facebook and YouTube), which was well managed but did not yet have a website as a promotional media and school profile. Third, documentation of activities and winning competitions was only recorded in notebooks; photos and championship records were separate, so when the data were needed, one had to search manually.

Hence, the website was developed using offline WordPress cms by utilizing a local server. Figure 1 is the offline development result on a local server.
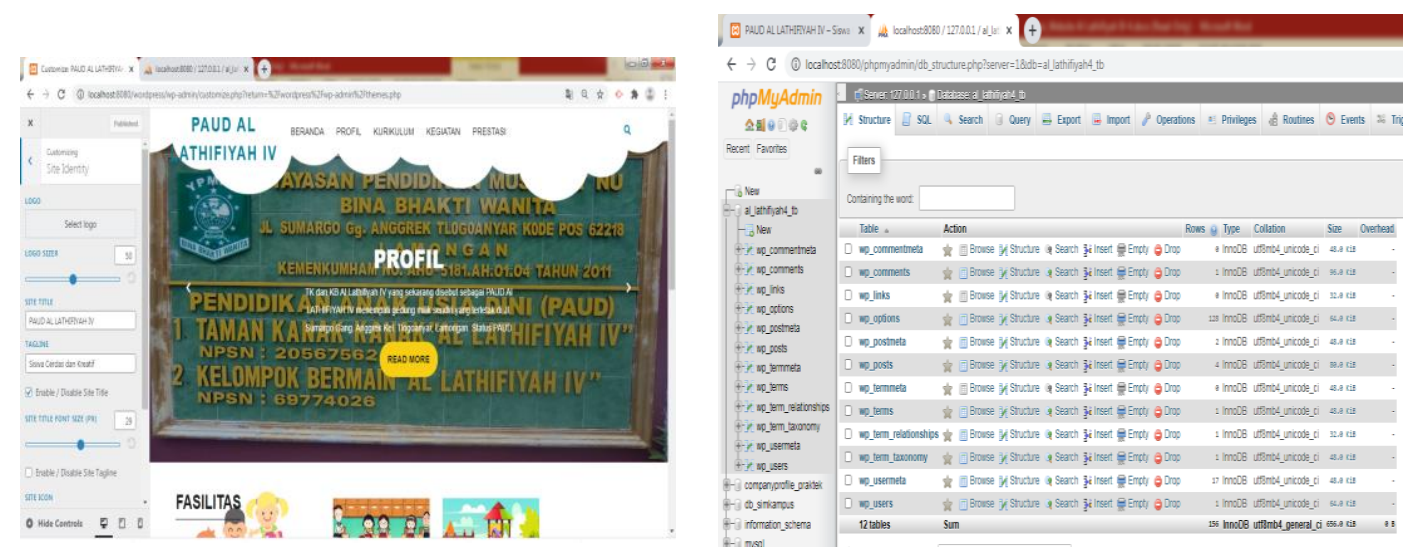

Figure 2. Offline Website Development

Figure 2 is the setting process; what databases and tables were used. After there were no errors during development, the PAUD AI Lathifiyah IV Lamongan website was ready to go online. Paid hosting and domains were selected, with the site address www.Al-Lathifiyah4.com. The PAUD Al Lathifiyah information website could be accessed using any browser on a cellphone, laptop, or computer device. The website's display was also responsive to the size of the hardware screen. 

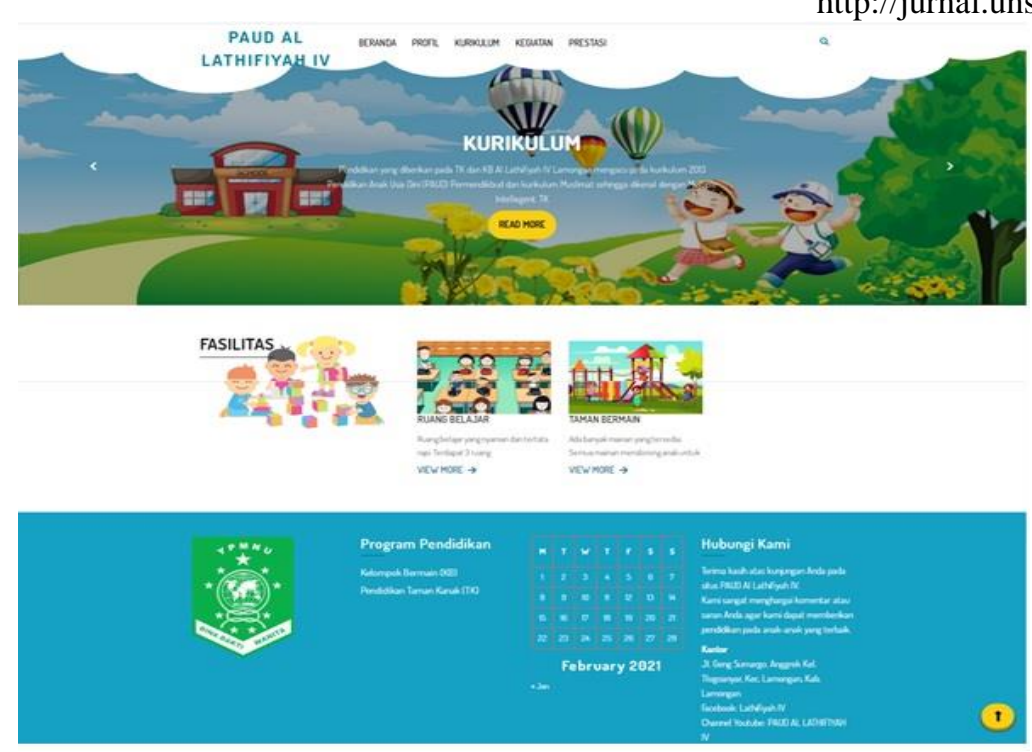

Figure 3. Home Page View

Figure 3 below is the home page; this page displayed facilities, profile snippets, the PAUD Al Lathifiyah curriculum, and contact information on PAUD AI Lathifiyah IV's whereabouts.

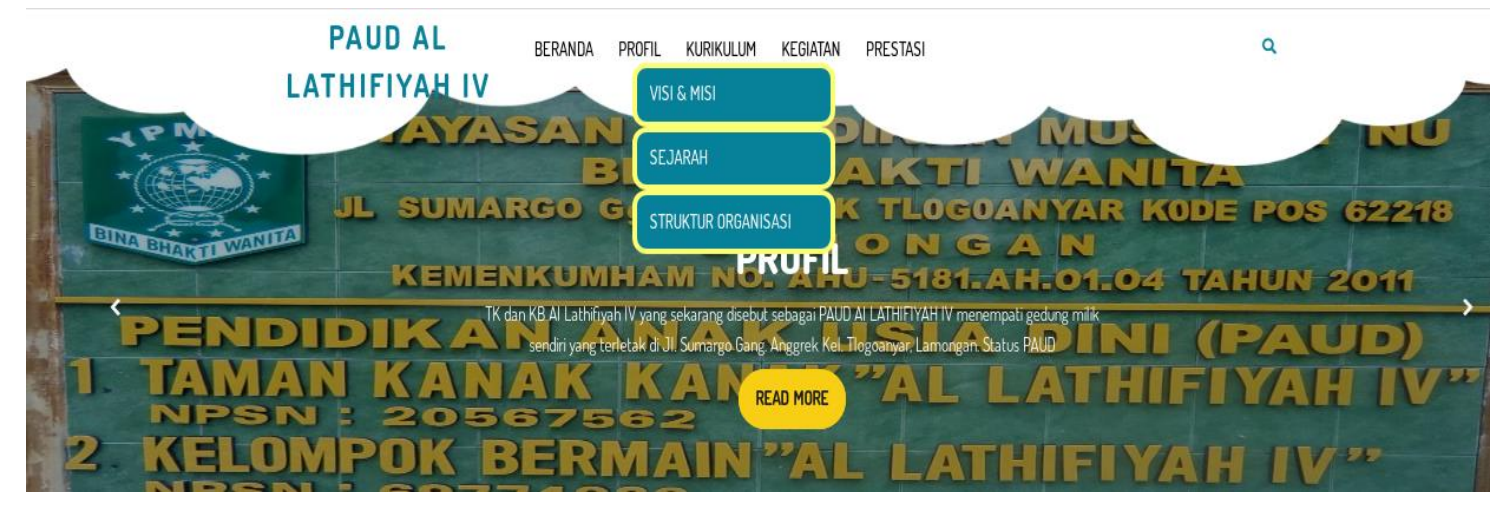

Figure 4. Navigation View

Figure 4 displays the menu available on the web, and the menu is at the top. A home menu and a profile consisted of the vision \& mission sub-menu and history. Moreover, there was a menu of organizational structure, curriculum menu, activities, and achievements. 

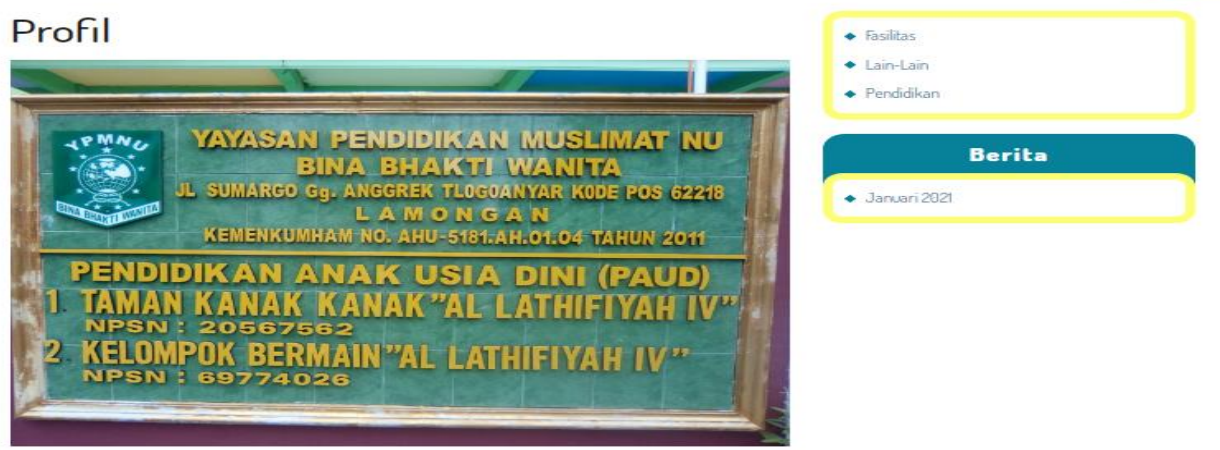

TK dan KB Al Lathifiyah IV yang sekarang disebut sebagai PAUD AI Geng Sumargo. Angriek Kel. Tlogoanyar. Lamongan. Status PAUD AI

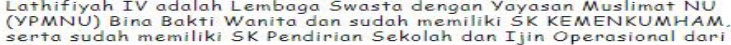

Figure 5. Profile Page
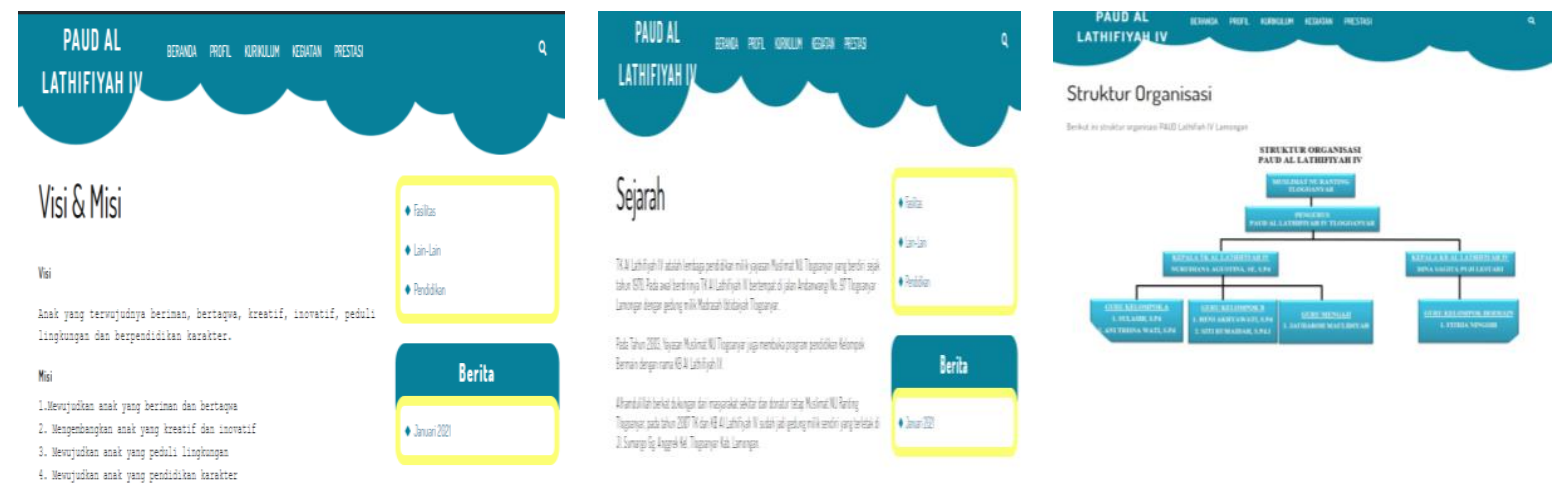

Figure 6. Vision \& Mission, History, and Organizational Structure Pages

Figure 5 is a profile page. The profile had three sub-menus: vision \& mission, history, and organizational structure. This profile aimed to provide information related to the PAUD AI Lathifiyah IV institution. The sub-menu of the profile page shown in Figure 6 aimed to provide information to visitors that PAUD AI Lathifiyah IV had a clear vision \& mission and organizational structure to educate children to be intelligent, innovative, and pious children. The history page aimed to show the year of its establishment and how PAUD AI Lathifiyah IV was developed. This page could be used to convince readers that PAUD AI Lathifiyah is an experienced early childhood education institution.

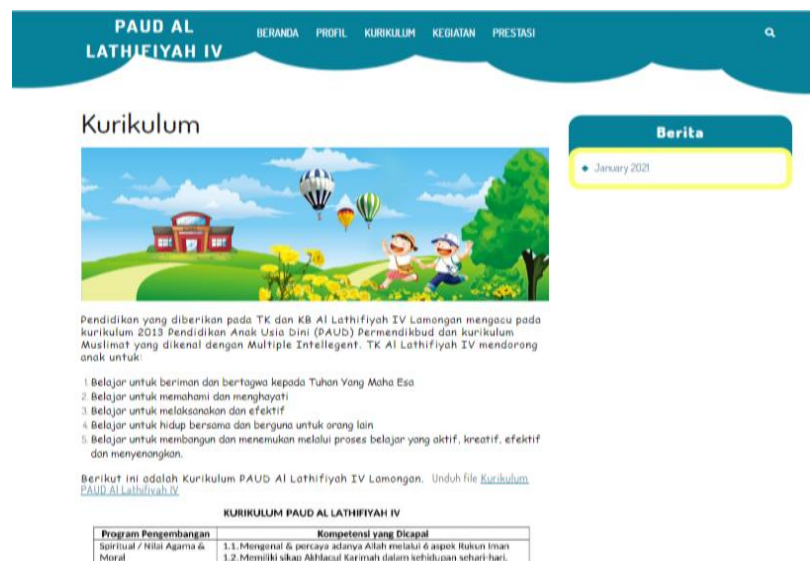

Figure 7. Curriculum Page 
Figure 7 is a curriculum page. This page contained the curriculum explanation used in PAUD Al Lathifiyah IV. Web visitors could view the curriculum page by selecting the menu. This page provided information to visitors about what curriculum or education young children would receive. Visitors could also download curriculum details in pdf form so that visitors could learn it more clearly.
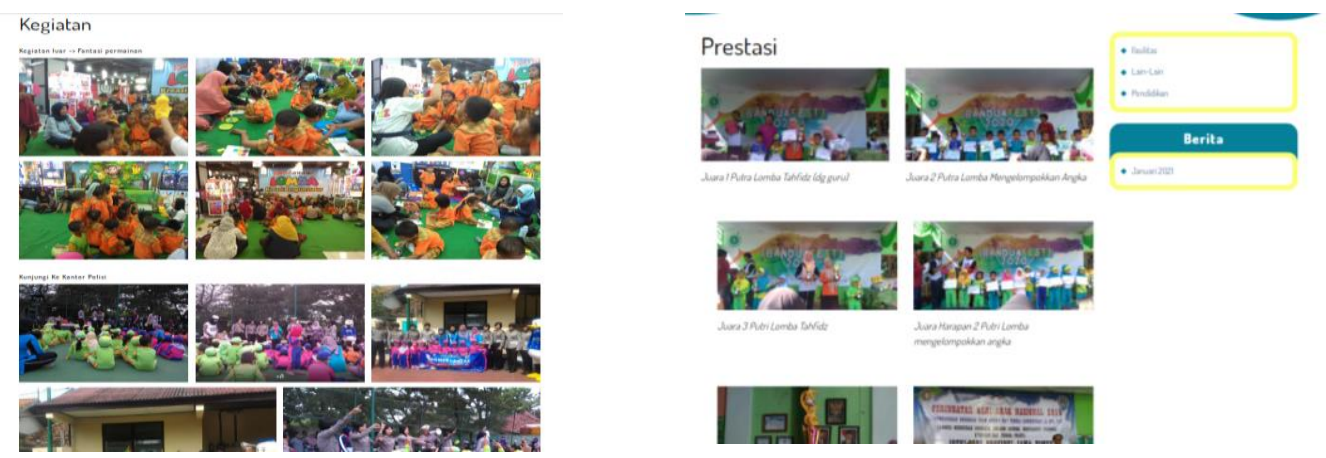

Figure 8. Activity and Achievement Page

Figure 8 is a picture of the activity page and the achievement page. These two pages were a gallery of what activities the children did, activities outside the classroom in collaboration with other agencies. This activity served to equip children to get to know the social environment and interact. The achievements page showed some achievements the kids have made. The purpose of this achievement page was a promotion and to convince visitors to enroll their sons and daughters to PAUD AI Lathifiyah IV.

After the website was online, it was tested by accessing the website through several types of browsers, namely Google Chrome, Edge, and Firefox. All results from accessing the website displayed a good and neat display. Apart from testing the website on several different types of browsers, the researcher also tried it on different devices, such as mobile phones and laptops, which had different screen sizes. The test results of these two different equipment types are presented in Table 1.

Table 1. Display Testing on Different Types of Devices

\begin{tabular}{lll}
\hline \multicolumn{1}{c}{ Ability } & \multicolumn{1}{c}{ Handphone } & \multicolumn{1}{c}{ Computer } \\
\hline Visual design & good, structured layout, and up-to-date & good, structured layout, and up-to-date \\
\hline Content & clear and easy to understand & clear and easy to understand \\
\hline Image & good and clear & good and clear \\
\hline Functionality & All menu work fine. & All menu work fine. \\
\hline
\end{tabular}

Based on Table 1, the PAUD AI Lathifiyah IV website's displays on the two types of devices were good, fast, and clear. Website display adjusted to the screen size (responsive). The PAUD AI Lathifiyah IV website could customize the display with cellphones with smaller screens. The difference in the website's responsiveness was the absence of a slider on the homepage and a hidden menu. Menus could only appear when the icon menu was clicked. However, all text and images were legible, and visitors could understand them. Figure 9 is the display on the mobile screen. 

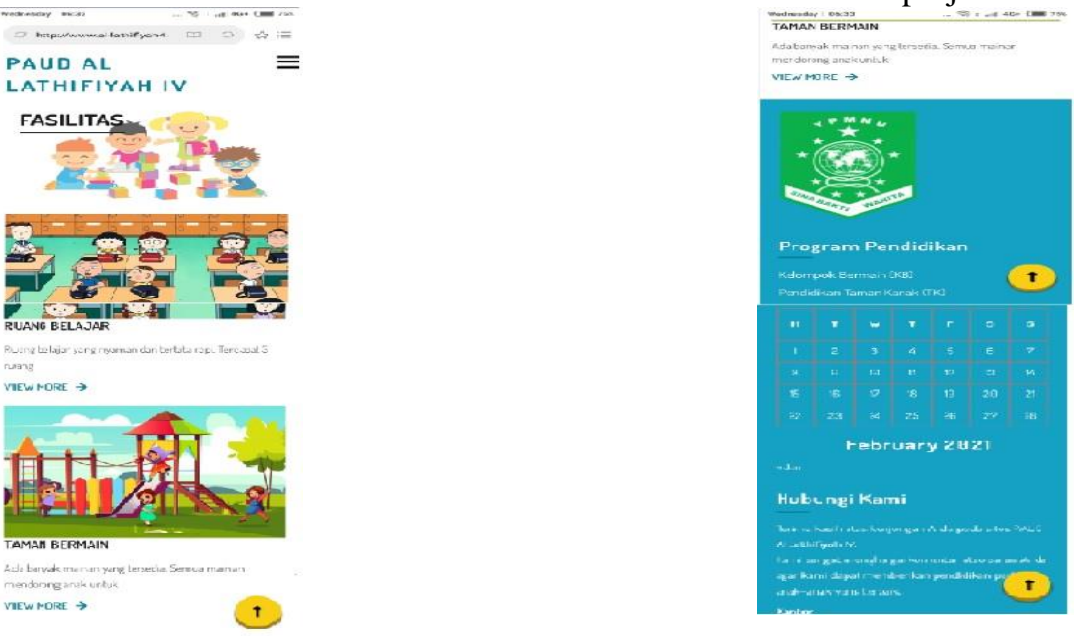

Figure 9. Display on the Mobile Screen

\section{Discussion}

The website theme used was good, simple, attractive, and amusing. This theme was suitable for early childhood education's concept. However, using this theme sometimes caused the website to be accessed for a long time when changing web pages, taking more than four seconds. The website address used for PAUD Al Lathifiyah IV was www.Al-Lathifiyah4.com. Next year, it is recommended that perhaps, it can be changed to the sch.id domain so that visitors have more confidence because the domain choice also affects trust level. As shown in Figure 9 and the previous figures (Figures 3 to 8), there were differences in the menu's display. On a mobile device, a menu would appear when clicking the icon $\equiv$ . It functions to maximize more explicit writing, especially the website's name. As stated (Saputra, 2018), the advantages of web applications that apply the responsive layout principle are that the information displayed on the website can be conveyed and received well by visitors without losing any information even if accessed from any mobile device.

Apart from testing the device on several different browsers and devices, testing was also carried out using GTMetrix. In this study, GTMetrix helped increase website loading speed and improve website performance so that website visitors would be pleased, and it attracted many visitors. The scoring and performance improvement rules used by GTMetrix combined Yahoo YSlow and Google Page Speed rules. Any missing sections were described in terms of deficiencies and recommendations according to Google Page Speed and Yahoo Yslow. Of course, it was done with links to related articles that recommend troubleshooting (Delta, 2016).

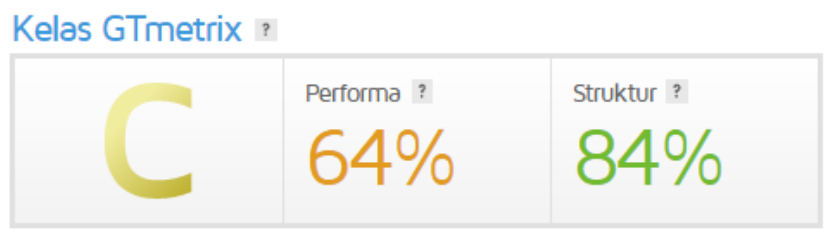

Figure 10. GTMetrix Test Results

Figure 10 exhibits the test results with GTMetrix. GTMetrix showed adequate results with a performance value of $68 \%$ and a structure value of $84 \%$. The details of this performance value included time to interactive and speed index. The time to interact revealed 1.7 seconds and the speed index was 4.9 seconds. Based on the time to be interactive, it was good; there was no need for improvement. However, although the access speed of 4.9 seconds was in the high category, there needs improvement. 
A good access speed should be less than 1.3 seconds. Meanwhile, the web structure's detailed value was quite good, requiring JavaScript or CSS optimization.

Based on GTMetrix testing, suggestions are given to improve website performance to be accessed more quickly. One of the suggestions given by GTMetrix is to improve the JavaScript or CSS structure that blocks the HTML structure. The advice given by GTMetrix implies that there needs to be a new, better template because the JavaScript and CSS that block it are part of the website template used.

\section{CONCLUSION AND SUGGESTION}

Based on the research results, it could be concluded that the creating PAUD AI Lathifiyah IV Lamongan Regency website as a promotional media and school profile could be applied and run well. The PAUD AI Lathifiyah IV website was also responsive to various devices (cellphones and laptops) so that information related to PAUD AI Lathifiyah IV Lamongan could be accessed anywhere and anytime by all people without having to go to school. With the PAUD AI Lathifiyah IV Lamongan website, the way of delivering information and promotion methods was much more effective. It then makes PAUD AI Lathifiyah IV a technology-based educational institution that is not outdated. Besides, the information obtained by the public is also more accurate than information obtained by word of mouth (WOM).

The suggestion for application improvements is that it needs further optimization on the PAUD Al Lathifiyah IV website. This optimization aims to speed up access to website performance and increase the page range on search engines. Therefore, the PAUD AI Lathifiyah IV website can always be on the first page of search engines. Regarding the research, the suggestion is that there is a need for further research on the PAUD AI Lathifiyah IV website's effectiveness as a promotional medium. Besides applying this research to other objects, the results and methods applied may differ because the time difference between the research and the research object will affect the research results.

\section{REFERENCES}

Afriansyah, R., Mubaroh, S., \& Pratiwi, I. R. (2021). Pembuatan Portal Website Sekolah SMA Negeri 1 Sungailiat Sebagai Media Informasi. DINAMISIA : Jurnal Pengabdian Kepada Masyarakat, 5(1), 154-160.

Andriyan, W., Septiawan, S., \& Aulya, A. (2020). Perancangan Website Sebagai Media Informasi dan Peningkatan. Jurnal Teknologi Terpadu, 6(2), 79-88.

Anhusadar, L. (2016). Kreativitas Pendidik Di Lembaga Paud. Al-Ta'dib, 9(1), 76-93.

Cooper, J., \& James, A. (2009). Challenges for Database Management in the Internet of Things. IETE Technical Review, 26(5).

Delta, E. N. (2016). Performance Test dan Stress Website Menggunakan Open Source Tools. Jurnal Manajemen Informatika, 6(1), 208-215. Retrieved from https://www.infodesign.org.br/infodesign/article/view/355\%0Ahttp://www.abergo.org.br/revista/inde x.php/ae/article/view/731\%0Ahttp://www.abergo.org.br/revista/index.php/ae/article/view/269\%0Aht tp://www.abergo.org.br/revista/index.php/ae/article/view/106.

GTMetrix. (2021). GTMetrix Performance Blog. Retrieved from https://gtmetrix.com/blog/everything-youneed-to-know-about-the-new-gtmetrix-report-powered-by-lighthouse/\#structure-score.

Hasugian, P. S. (2018). Perancangan Website Sebagai Media Promosi. Journal Of Informatic Pelita Nusantara, 3(1), 82-86.

Ilyasir, F. (2020). Pendidikan demokratis di era revolusi industri 4.0, 7(1), 60-69.

Mubarok, E. A. (2017). Anak Bukan Miniatur Orang Tua. Retrieved from 
https://radarbojonegoro.jawapos.com/read/2017/08/31/10853/anak-bukan-miniatur-orang-tua

Musfiroh, T. (2008). Bermain Sambil belajar dan Mengasah Kecerdasan. Jakarta: Depdiknas.

Prawira, J. J. C. ., \& Wardani, T. I. (2017). Aplikasi CMS Wordpress Untuk Pembuatan Website Sebagai Media Promosi di Wisata Keramik Dinoyo. J A B Jurnal Aplikasi Bisnis, 3(2), 578-583.

Rahelly, Y. (2018). Implementasi Kurikulum 2013 Pendidikan Anak Usia Dini ( PAUD) di Sumatera Selatan. Jurnal Pendidikan Usia Dini, 12(November), 381-390.

Rochman, A., Hanafri, M. I., \& Wandira, A. (2020). Implementasi Website Profil SMK Kartini Sebagai Media Promosi dan Informasi Berbasis Open Source. AJCSR (Academic Journal of Computer Science Research), 2(1), 46-51. Retrieved from https://stmikglobal.ac.id/journal/index.php/AJCSR/article/view/272.

Saputra, D. (2018). Teknik Dasar Tampilan Responsif Pada Website. Retrieved from https://www.dicoding.com/blog/dasar-tampilan-responsif-pada-website/.

Sumantri. (2005). Model Pengembangan Keterampilan Motorik Anak Usia Dini. Jakarta: Departemen Pendidikan Nasional.

www.kominfo.go.id. (2020). Dirjen PPI: Survei Penetrasi Pengguna Internet di Indonesia Bagian Penting dari Transformasi Digital. Retrieved from https://www.kominfo.go.id/content/detail/30653/dirjen-ppisurvei-penetrasi-pengguna-internet-di-indonesia-bagian-penting-dari-transformasidigital/0/berita_satker\#: :text=Hasil Survei APJII,-Sekretaris Jenderal APJII.

Yani, I. E., \& Indrawati. (2014). Persepsi Orangtua Tentang PAUD (Studi Yayasan Bina Insan Mandiri Kelurahan Simpang Baru Kecamatan Tampan Kota Pekanbaru). Jurnal Online Mahasiswa Fakultas IImu Sosial Dan IImu Politik, 1(1), 2-5. https://doi.org/10.12681/eadd/1834.

How to cite: Nurfauziah, S. (2021). Development of Information Website for PAUD Al Lathifiyah IV as Promotion Media and School Profiles. Teknodika, 19 (1), 71 - 81. DOI: https://doi.org/10.20961/teknodika.v19i1.48357 